UDC 338.2:330.34:658

JEL Classification: E61, 012, M29

DOI: 10.15587/2312-8372.2019.159733

\title{
Stecenko I. \\ THE ANALYSISS OF IMPACT OF SMALL AND MEDIUM-SIZED ENTERPRISES ON COUNTRY INNOVATION POLICY: TAIWAN EXPERIENCE
}

Об’єктом дослідження є малі і середні підприємства (МСП) Тайваню. Реалізація програми Свропа-2020 побудова інноваційної економіки краӥн Свропейського Союзу (EC) - є пріоритетним напрямком СС. У Латвї, як в середньому і в СС, 99,8\% підприємств є МСП. Пошук індикаторів, що впливають на створення інноваційної економіки і включення в інноваційну середу підприємств малого $і$ середнього бізнесу є проблемою не тільки для Латвї, країн Балтї, а й в цілому для всього СС. Тайвань є одним з «азіатських тигрів», який зробив величезний економічний стрибок з аграрної держави в індустріальну. Випуск в 2016 році низки високотехнологічних продуктів, таких як: материнські плати - 89,7\% світового ринку, кабельне СРЕ-обладнання 84,5\% і ноутбуки - 83,5\% світового ринку, ставлять краӥну в ряд крайн з інноваційною економікою. Тому аналіз досвіду Тайваню в побудові інноваційної економіки заслуговує додаткового вивчення і реалізачї його в інших країнах.

Для дослідження автор використовував такі методи: контент аналіз - джерела інформацї були систематизовані, а чисельні показники оброблені, оцінені і інтерпретовані, $i$ статистичний аналіз - метод кореляції Пірсона, Спірмена $і$ Тау Кендалла. За допомогою цих методів відібрані показники, що впливають на кількість МСП. В ході проведеного теоретичного аналізу автор сформулював переваги малого i середнього бізнесу, провів пошук показників, що впливають на малі і середні підприємства $і$ залучення їх в інноваційну середу Тайваню.

Встановлення лінійного взаємозв'язку і використання кореляційного аналізу з використанням програми SPSS дозволило автору знайти взаємозв'язок між показниками:

- кількість дослідників (в еквіваленті повної зайнятості);

- щорічні статті в індексі наукового щитування (SCI);

- щорічний звіт щодо інженерного індексу (EI);

- кількість малих і середніх підприємств;

- загальна зайнятість малих і середніх підприємств;

- кількість зареєстрованих патентів.

Використання взаємопов'язаних індикаторів вирішує важливу економічну задачу - підвищення рівня життя населення за рахунок інновацій. Оцінка даних показників в країнах СС за допомогою економетричних методів дозволить реалізовувати інноваційну політику держав.

Ключові слова: підприємства малого і середнього бізнесу на Тайвані, інноваційна політика, економічна політика країн $Є C$.

\section{Introduction}

Innovation is the dynamic force that changes the economy. It provides new products and processes. It generates productivity growth and leads to increases in the standard of living. It is at heart of entrepreneurship [1]. Innovators differ from non-inovators in that they adopt a purpose stance to final new productsand to adopt new processes.

Considerable of economic research has been devoted to establishing whether small and large firms differ with regard to the rate of innovation or their reserch and development $(R \& D)$ activity.

Because Taiwan is one of the «Asian tigers», which made a huge economic jump-start from an agrarian country to an industrial one, therefore relevant is the research of birth of small and medium-sized enterprises and the implementation of country's innovation policy.

\section{The object of research and its technological audit}

The object of research is the small and medium size enterprises (SMEs) of Taiwan.

In the strategy «Europe 2020», which was adopted in 2010 by the European Commission paid a lot of attention to joining efforts of the European Union (EU) countries for the purposes of formation and practical introduction of innovations that will provide the opportunity to apply new ideas in the production of new ideas, services [2]. EU regional policy funding focuses on 4 priorities:

1. Research \& innovation.

2. Information \& communication technologies.

3. Making small and medium-sized businesses more competitive.

4. Moving towards a low-carbon economy. 
As it is possible to see from this document - from 4 priority directions of EU regional policy, the author research's object explores the interaction of two directions - SMEs and innovations. The complexity involvement of SME in innovation process base on the small size of firms and, as a rule, the lack of financial resources for innovation.

\section{The aim and objectives of research}

The aim of research is assessing the influence of small and medium-sized enterprises (SMEs) in the innovation field of Taiwan.

To achieve this aim, it is necessary to solve the following tasks:

1. To comprehend what are the advantages and disadvantages in the implementation of SMEs activities.

2. To analyze the indicators affecting the creation of SMEs and innovation activity.

3. Based on the econometrics methods to estimate the indicators influencing on the formation of SMEs of Taiwan and their innovative activities.

\section{Research of existing solutions of the problem}

According to the Global Competitiveness Index (GCI), Taiwan has 15th place in the World (Latvia has 54th place) on the level of business development an11th place in innovation in 2016-2017 (Latvia has 83th place in innovation) [3]. According to the annual report of the European Commission on the successes of EU memberstates in the field of innovative activity of the «Innovation Union Scoreboard», Latvia is still lagging behind on innovative development among other EU countries [4]. In Taiwan, small and medium-sized enterprises (SMEs), playing a very important role to the country's economic growth, accounting for almost $99.8 \%$ of overall enterprises and employing almost $78 \%$ of all employees [5]. Let's represent the costs of some EU countries for Research and development in the form of Table 1.

Table 1

Research and development expenditure, by sectors of performance, \% of GDP*

\begin{tabular}{|l|c|c|c|}
\hline \multicolumn{1}{|c|}{ Countries } & 2015 & 2016 & 2017 \\
\hline EU (28 countries) & 2.04 & 2.03 & 2.07 \\
\hline Euro area (19 countries) & 2.14 & 2.13 & 2.17 \\
\hline Germany & 2.92 & 2.94 & 3.02 \\
\hline France & 2.27 & 2.25 & - \\
\hline Estonia & $\mathbf{1 . 4 9}$ & $\mathbf{1 . 2 8}$ & $\mathbf{1 . 2 9}$ \\
\hline Latvia & $\mathbf{0 . 6 3}$ & $\mathbf{0 . 4 4}$ & $\mathbf{0 . 5 1}$ \\
\hline Lithuania & $\mathbf{1 . 0 4}$ & $\mathbf{0 . 8 5}$ & $\mathbf{0 . 8 8}$ \\
\hline Finland & 2.9 & 2.75 & 2.76 \\
\hline Sweden & 3.27 & 3.25 & 3.33 \\
\hline Denmark & 2.96 & 2.87 & 3.06 \\
\hline Taiwan** & 3.04 & 3.16 & - \\
\hline
\end{tabular}

Note: ${ }^{*}$ - developed by the author on the basis of data $[6] ;{ }^{* *}-[7]$
As it is possible to see from the data represented in the Table 1, in 2016 the indicator of costs for $R \& D$ in Germany and France made up $2.94 \%$ and $2.25 \%$. However, the average indicator of costs for R\&D for EU-28 countries in 2016 made up $2.03 \%$ and in euro-zone countries $2.13 \%$. This with the existing goal of the program 2020 by 2020 the average indicator for the EU countries, but R\&D should be $3 \%$ ! In the Baltic countries, the situation with the implementation of a plan on the costs for $R \& D$ looks deplorable, for example, in Estonia in 2016 costs for R\&D made up $1.28 \%$, in Lithuania $0.85 \%$ and in Latvia only $0.44 \%(!)$. Here, it should be noted that for Baltic States, costs for according to the program 2020 is Latvia $1.5 \%$ of GDP, Lithuania $1.9 \%$ and Estonia $3.0 \%$ of GDP. However, as it is possible to see from the data, represented in the Table 1 only Estonia has approached this indicator, neither Latvia nor Lithuania fulfill the program objectives that makes the research represented perspective. The analysis of the Baltic Sea countries - Sweden, Denmark and Finland showed that they successfully fulfill the R\&D indicators set by the Europe 2020 program. Thus, in 2016 costs for R\&D in Sweden made up $3.25 \%$, Denmark $2.87 \%$ and Finland $2.85 \%$ of GDP, respectively. In Latvia the greatest problem of deterrence of innovation activity is the fact that small and medium-sized businesses dominate in the country, covering about $99.8 \%$ of all enterprises, which don't have enough funds and skilled staff for the implementation of investments in the innovative projects [8]. According to the statistical data for previous periods in 2014 in Latvia $23.4 \%$ of enterprises on average were innovative, but this average indicator in the countries of the European Union makes up $52 \%$ [9]. In the research of the innovation policy and innovation process in the complex are used such definitions as: innovations, research and development. Since research and development it is seen to have a special and key role in the innovation process. The research we are conducting needs to define these categories. Research is original investigation undertaken on a systematic basis to gain new knowledge. Development is the application of research findings or other scientific knowledge for the creation of newor significantly improved products or processes [10,11]. So, innovations. European Commission provides definition for innovation: a new or changed product is introduced to the market, or when a new or changed process is used in commercial production [12].

\section{Methods of research}

The methodology assumes the system approach to the problem solving, providing unity of qualitative and quantitative methods:

- monographic and document analysis method makes it possible to carry out the research object a detailed study of to comprehend what are the advantages and disadvantages in the implementation of SMEs activities;

- content analysis used to grasp what are role of SMEs in the economy of European Union and their innovation activities;

- using statistical and graphical analysis method author of the study to analyze of the indicators affecting on the creation of SMEs and their innovation activity (correlation analysis, regression analysis). 


\section{Research results}

Can SMEs be included in the innovation process? There are several reasons why small firms concentrate on the innovation efforts. First, these breakthroughs where small firms may be particularly common for the types of processes in which firm specialize. Second, they may occur because the comparative advantage of large firms lies in the production of the type of knowledge that originates in $R \& D$ facilities, since the costs of conducting $R \& D$ for large firms are lower because specialization of function means that large firms will enjoy cost advantages in the pure R\&D function [13]. A small firm may be just an innovative, but the may innovate in unique ways. Most previous studies have focused on the whether R\&D expenditures increase more scale in the $R \& D$ function or whether $R \& D$ expenditures increase more than proportionally with firm size [14, 15].

The innovation system is complex: some firms are traditionally R\&D laboratories, whereas others develop alliances and joint ventures that allow them to tap into scientific work being done elsewhere. $R \& D$ labs are frequently large and costly, and economies of scale associated there with may prevent small firms from constructing their own facilities very frequently.

A SMEs firm may solve the problem by forming partnerships with other firms. SMEs may offset advantages in terms of flexibility and response time to customer needs (Table 2).

Table 2

Advantages and disadvantages of small and medium-sized enterprises in innovations

\begin{tabular}{|l|l|}
\hline \multicolumn{1}{|c|}{ Advantages } & \multicolumn{1}{c|}{ Disadvantages } \\
\hline $\begin{array}{l}\text { Smaller firms take decisions faster } \\
\text { and implement them more rapidly }\end{array}$ & $\begin{array}{l}\text { Not to provide the diversification of } \\
\text { scientific studies and knowledge, to } \\
\text { focus significant resources on one } \\
\text { direction and develop capital - in- } \\
\text { tensive innovations }\end{array}$ \\
\hline $\begin{array}{l}\text { Small firms focus on technical ca- } \\
\text { pability }\end{array}$ & $\begin{array}{l}\text { There is no network for distribution, } \\
\text { the marketing department }\end{array}$ \\
\cline { 1 - 1 } $\begin{array}{l}\text { Small firms exhibitthe sameflexibility } \\
\text { in their R\&D that they showin many } \\
\text { of their operations }\end{array}$ & \\
\cline { 1 - 2 } $\begin{array}{l}\text { Small firms also benefit from the B\&D } \\
\text { done in large firms because a larger } \\
\text { proportion of their innovation are } \\
\text { the result of liaisons with customers }\end{array}$ & \\
\cline { 1 - 2 } $\begin{array}{l}\text { More flexible in creating the alliances } \\
\text { with other firms, in developing and } \\
\text { changing the strategy }\end{array}$ & \\
\cline { 1 - 2 } $\begin{array}{l}\text { Size. Their smaller size makes smal- } \\
\text { ler markets attractive to SMEs while } \\
\text { these markets would not be attractive } \\
\text { for larger firms }\end{array}$ & \\
\hline
\end{tabular}

Note: ${ }^{*}$ - developed by the author base on [13]

However, the main advantage of SMEs under conditions of globalization, it is internationalization in small states, such as Latvia, Lithuania, Estonia and etc. The basic rules for the formation of SMEs are described in the Standards for Identifying Small and Medium-sized Enterprise: SMEs paid-in capital of 80 million USD or less, or less than 200 regular employees. Sales revenue of 100 mil- lion USD or less in the previous year, or has less than 100 regular employeesor less than 80 million USD, which equals 2.42 million USD for manufacturing, construction, mining, and quarrying industries. This means that if either criterion is met, the business qualifies as an SME. In 13 service and commerce sectors, micro enterprises are defined by having fewer than 5 employees while SMEs must have fewer than 50 employees, and a preceding year sales revenue of less than 100 million USD, which equals 3.03 million USD [15]. In the low introduces thedefinition «small-scale enterprise» - small-scale enterprise - less than 5 regular employees. For comparison, let's mention the requirements for the classification of SMEs in the European Union countries (Table 3).

Table 3

The classification of micro, small and medium-sized enterprises in EU recommendation 2003/361*

\begin{tabular}{|c|c|c|c|}
\hline Company category & Staff headcount & Turnover & Balance sheet total \\
\hline Medium-sized & $<250$ & $\leq 50 \mathrm{mln}$ EUR & $\leq 43 \mathrm{mln}$ EUR \\
\hline 5mall & $<50$ & $\leq 10 \mathrm{mln}$ EUR & $\leq 10 \mathrm{mln}$ EUR \\
\hline Miсго & $<10$ & $\leq 2 \mathrm{mln}$ EUR & $\leq 2 \mathrm{mln}$ EUR \\
\hline
\end{tabular}

Note: ${ }^{*}$ - developed by the author on the basis of data [6]

As it is possible to see from the represented analysis the requirements for the creation of SMEs in the EU countries are somewhat higher, it concerns the number of employees up to 250 people, in Taiwan 200 people. In the EU the requirements for the turnover for SMEs are set (Table 4) or to Balance sheet total, in Taiwan as the criterion serve revenue.

Thus, the selection of indicators for the assessment of the dynamics of SMEs is implemented in 3 approaches it is the choice of dynamic and social indicators. So, the first group of indicators is related to the macroeconomic indicators of the country. Undoubtedly, innovation activity is influenced by the indicator of the costs for research and development, which assesses the international organizations such as the World Economic Forum, the level of gross domestic product per inhabitant is the basic indicator - for both all external assessments and internal assessments of the state - International Monetary Found, World Trade Organization and others.

Since the subject of this research is an innovative sphere, undoubtedly, in the opinion of the author such a group of indicators as:

- Number of Researchers (full time equivalent);

- Annual Papers in Science Citation Index (SCI);

- Annual Papers in Engineering Index (EI);

- Patents Granted in USA and we also include in the research the Number of Students.

It is necessary to include in the research for the assessment of influence on the innovation sector and the third group of indicators is directly related to SMEs:

- Number of SMEs;

- Total Employment SMEs;

- Total Sales Value of SMEs.

Data on which are included in studies due to the Ministry of Economic Affairs of Taiwan (MOEA) [15].

In Fig. 1 the author represents a diagram of growth dynamics of researchers and their publications. 
The dynamics of economic and social indicators, influencing on innovations from 2008 to $2015 *$

\begin{tabular}{|l|c|c|c|c|c|c|c|c|}
\hline \multicolumn{1}{|c|}{ Indic/year } & 2008 & 2009 & 2010 & 2011 & 2012 & 2013 & 2014 & 2015 \\
\hline GDP Per Capita, USD & 18.131 & 16.988 & 19.278 & 20.939 & 21.308 & 21.916 & 22.648 & 22.384 \\
\hline R\&D Expenditure as \% of GDP, percent years & 2.78 & 2.83 & 2.80 & 2.89 & 2.94 & 2.99 & 3.00 & 3.05 \\
\hline Unemployment Rate, \% & 4.1 & 5.9 & 5.2 & 4.4 & 4.2 & 4.2 & 4.0 & 3.8 \\
\hline Higher Education amount, million USD & 3.441 & 3.683 & 3.797 & 3.918 & 3.965 & 3.912 & 3.844 & 3.718 \\
\hline $\begin{array}{l}\text { Number of Researchers (full time equivalent), } \\
\text { person-years }\end{array}$ & 110.089 & 119.185 & 127.768 & 134.048 & 139.215 & 140.124 & 142.983 & 145.381 \\
\hline Annual Papers in Science Citation Index (5CI), papers & 22.756 & 23.778 & 24.921 & 27.283 & 27.639 & 27.699 & 27.430 & 26.715 \\
\hline Annual Papers in Engineering Index (EI), papers & 17.483 & 18.869 & 20.302 & 22.819 & 20.729 & 24.415 & 22.706 & 19.822 \\
\hline Patents Granted in USA, cases & 6.339 & 6.642 & 8.238 & 8.781 & 10.646 & 11.071 & 11.332 & 11.690 \\
\hline $\begin{array}{l}\text { Number of Students, Higher Education Bachelor } \\
\text { programme }\end{array}$ & 1.006 .102 & 1.010 .952 & 1.021 .682 & 1.033 .035 & 1.038 .136 & 1.035 .654 & 1.037 .178 & 1.035 .356 \\
\hline Number of Students, Gradueted School & 213.700 & 217.152 & 219.252 & 217.890 & 215.930 & 208.908 & 203.564 & 199.815 \\
\hline Number of SMEs & 1.234 .749 & 1.232 .025 & 1.247 .998 & 1.279 .784 & 1.306 .729 & 1.331 .182 & 1.353 .049 & 1.383 .981 \\
\hline Total Sales Value of SMEs, million USD & 10.462 .696 & 9.189 .463 & 10.709 .005 & 100.770 & 11.381 .8 & 11.321 .842 & 11.839 .868 & 11.803 .100 \\
\hline Total Employment SMEs, thousend persons & 7.966 & 8.066 & 8.191 & 8.337 & 8.484 & 8.588 & 8.669 & 8.759 \\
\hline Total Sales Value of Large enterprises, million USD & 24.776 .441 & 689.448 & 756.519 & 806.127 & 26.267 .306 & 27.139 .052 & 28.400 .638 & 27.072 .200 \\
\hline Total Employment Large Company, thousend persons & 1.479 & 1.173 & 1.253 & 1.334 & 1.349 & 1.359 & 1.387 & 1.024 \\
\hline
\end{tabular}

Note: ${ }^{*}$ - developed by the author on the basis of data [15]

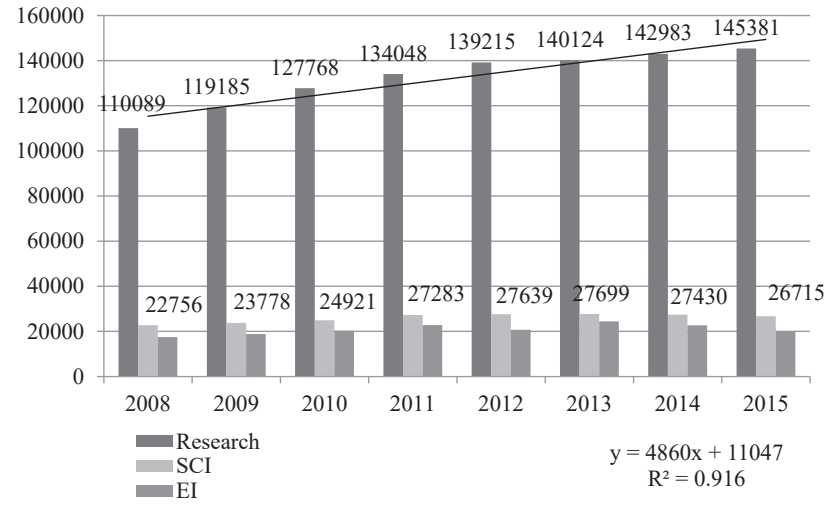

Fig. 1. The dynamics of change of researchers and publications in cited databases SCI and EI in Taiwan 2008-2015

The calculated coefficient of determination $\left(R^{2}=0.916\right)$ shows a high level of dependence between the quantities represented. Further, let's represent in Fig. 2 the dynamics of the change of the number of researchers and growth in the number of SMEs and employed in the field of SMEs in Taiwan.

The calculated coefficient of determination $\left(R^{2}=0.991\right)$ shows a high level of dependence between the represented quantities. It is interesting to examine the number of enterprises and the number of patents, Fig. 3.

Fig. 3 shows a linear variation of the number of patents, the level of GDP per capita and the number of registered SMEs. The calculated coefficient of determination $\left(R^{2}=0.854\right)$ shows a high level of dependence between the quantities represented. However, undoubtedly, not all registered SMEs in Taiwan are engaged in innovation activity. According to a survey conducted by the MOEA in 2014.

Table 5 represent how the financial resources are distributed in enterprises of Taiwan in the period from 2011-2015, depending on the number of employees of enterprises.

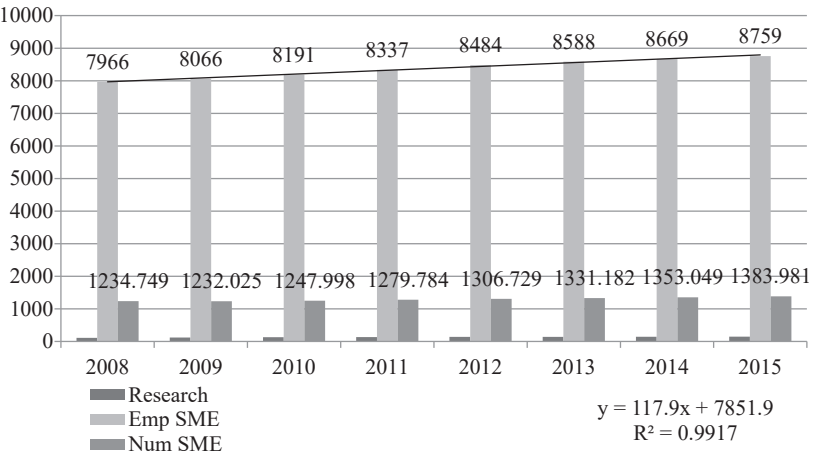

Fig. 2. The dynamics of change of the number of researchers, the number of employed in small and medium-sized enterprises (5MEs) and the number of SMEs in Taiwan in 2008-2015

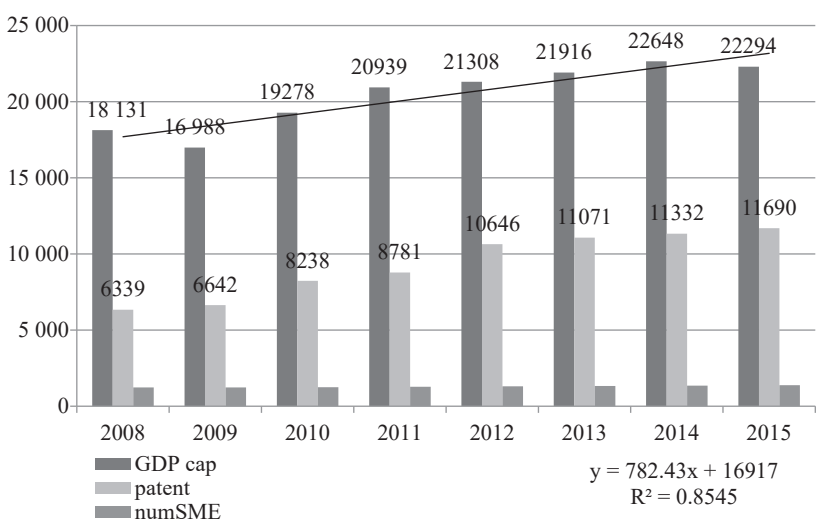

Fig. 3. Dynamics of changes of GDP per capita, the number

of small and medium-sized enterprises and the number of patents, registered in the USA

Thus, the MOEA analysis shows that enterprises spend significant funds in $\mathrm{R} \& \mathrm{D}$. Along with this in small firms 
(up to 99 people) more money is spent on $\mathrm{R} \& \mathrm{D}$, obviously, it is because of a large number of enterprises in Taiwan. Leadership in $\mathrm{R} \& \mathrm{D}$, undoubtedly for large companies - in Fig. 4 it is clearly visible.

Table 5

Business Sector R\&D Expenditure by Enterprise Size, 2011-2015, mln USD*

\begin{tabular}{|c|c|c|c|c|}
\hline Years & $\begin{array}{c}0-99 \\
\text { employment }\end{array}$ & $\begin{array}{c}100-199 \\
\text { employment }\end{array}$ & $\begin{array}{c}200-499 \\
\text { employment }\end{array}$ & $\begin{array}{c}500< \\
\text { employment }\end{array}$ \\
\hline 2011 & 23.431 & 20.434 & 40.889 & 215.604 \\
\hline 2012 & 24.725 & 20.488 & 45.561 & 229.132 \\
\hline 2013 & 24.701 & 22.66 & 46.593 & 249.501 \\
\hline 2014 & 24.701 & 22.66 & 50.21 & 270.1 \\
\hline 2015 & 27.574 & 24.299 & 49.984 & 295.306 \\
\hline Total & 125.132 & 110.541 & 233.237 & 1259.643 \\
\hline
\end{tabular}

Note: ${ }^{*}$ - developed by the author on the basis of data [6]

Further, let's calculate how companies of Taiwan for 5 years spent funds on R\&Dand the obtained calculations, we will represent in the form of Fig. 5.

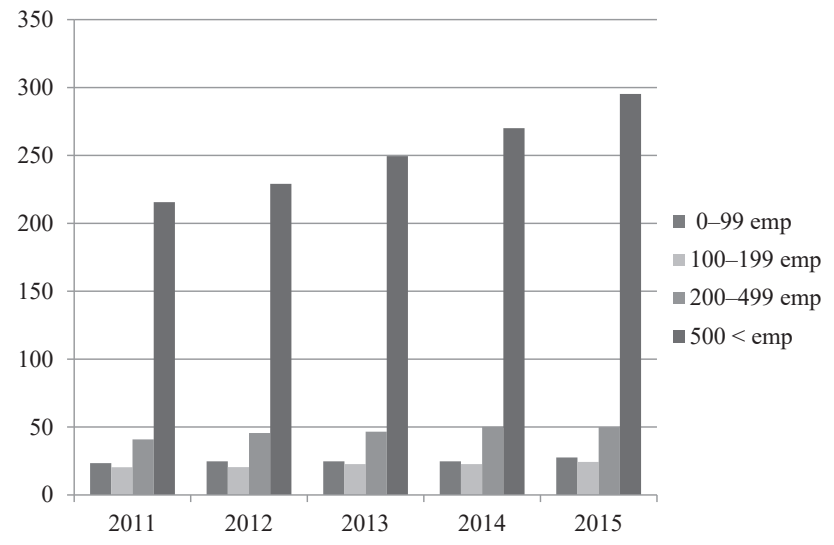

Fig. 4. Business Sector R\&D Expenditure by Enterprise Size, 2011-2015, mln USD

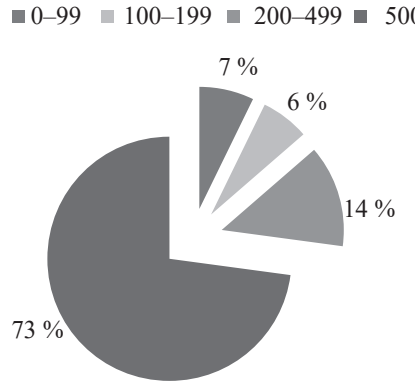

Fig. 5. R\&D Expenditure by Enterprise Size, 2011-2015, mln USD

The calculations carried out by the author from 2011 to 2015 show that firms with up to 99 people spent $7 \%$ of total investments by Taiwan enterprises in R\&D. Firms from 100 to 199 people invested $6 \%$ in total costs in R\&D. On companies from 200 to 499 employees account for almost one third of all investments $-14 \%$ and companies with more than 500 employees account for $73 \%$ of costs for R\&D. Thus, in aggregate to the large business of Taiwan - more than 200 people, working account for $13 \%$ of investments in R\&D, but SMEs account for $73 \%$ that makes up almost one third. Undoubtedly, this is significant financial investments in the economy of the state.

Further, to find the relationship between the coefficients, using the correlation analysis, let's make a calculation between the represented values. Thus, the correlation analysis is carried out by 3 methods: correlation of Pearson, Spearman and Tau Kendall (Tables 6, 7).

The value of correlation coefficient ranges from -1 to 1 . In the Table 8 is represented the possible correlation coefficient and corresponding characteristics of force and direction of dependence.

Using the Excel, let's make the calculation of Pearson correlation, taking into account the lack of scatters between the variables, which are shown in the form of regression analysis carried out by the author Fig. 1-3 between GDPper capita and the number of registered patents. The level of correlation was 0.956656 , but the level of correlation between GDP per capita and number of SMEs -0.953389 that show very strong correlation (Table 9).

Table 6

The correlation coefficients of Pearson, Spearman and Tau Kendall, using the SPSS program (Statistical Package for the Social Sciences)

\begin{tabular}{|c|c|c|c|c|c|c|c|c|c|}
\hline \multicolumn{2}{|c|}{ Indicators } & $\begin{array}{c}\text { R\&D } \\
\% \text { GDP }\end{array}$ & $\begin{array}{c}\text { Number } \\
\text { of Research }\end{array}$ & $\begin{array}{c}\text { Papers } \\
\text { of SCI }\end{array}$ & $\begin{array}{c}\text { Papers } \\
\text { of EI }\end{array}$ & $\begin{array}{c}\text { Number } \\
\text { of Students }\end{array}$ & $\begin{array}{l}\text { Number } \\
\text { of SMEs }\end{array}$ & $\begin{array}{l}\text { Employed } \\
\text { of } 5 \mathrm{MEs}\end{array}$ & Patents \\
\hline \multirow{2}{*}{$\mathrm{R} \& D$ \% GDP } & Pearson Correlation & 1 & $0.906^{* *}$ & $0.891^{* *}$ & $0.836^{*}$ & 0.145 & $0.971^{* *}$ & $0.968^{* *}$ & $0.940^{* *}$ \\
\hline & Significant (2-tailed) & - & 0.005 & 0.007 & 0.019 & 0.756 & 0.000 & 0.000 & 0.002 \\
\hline \multirow{2}{*}{ Number of Research } & Pearson Correlation & $0.906^{* *}$ & 1 & $0.972^{* *}$ & $0.880^{* *}$ & 0.056 & $0.906^{*}$ & $0.969^{* *}$ & $0.964^{* *}$ \\
\hline & Significant (2-tailed) & 0.005 & - & 0.000 & 0.009 & 0.906 & 0.005 & 0.000 & 0.000 \\
\hline \multirow{2}{*}{ Papers of 5CI } & Pearson Correlation & $0.891^{* *}$ & $0.972^{* *}$ & 1 & $0.895^{* *}$ & 0.154 & $0.874^{*}$ & $0.934^{* *}$ & $0.930^{* *}$ \\
\hline & Significant (2-tailed) & 0.007 & 0.000 & - & 0.006 & 0.741 & 0.010 & 0.002 & 0.002 \\
\hline \multirow{2}{*}{ Papers of EI } & Pearson Correlation & $0.836^{*}$ & $0.880^{* *}$ & $0.895^{* *}$ & 1 & 0.390 & $0.818^{*}$ & $0.868^{*}$ & $0.833^{*}$ \\
\hline & Significant (2-tailed) & 0.019 & 0.009 & 0.006 & - & 0.387 & 0.025 & 0.011 & 0.020 \\
\hline \multirow{2}{*}{ Number of SME } & Pearson Correlation & $0.971^{* *}$ & $0.906^{* *}$ & $0.874^{*}$ & $0.818^{*}$ & -0.044 & 1 & $0.981^{* *}$ & $0.965^{* *}$ \\
\hline & Significant (2-tailed) & 0.000 & 0.005 & 0.010 & 0.025 & 0.926 & - & 0.000 & 0.000 \\
\hline \multirow{2}{*}{ Employed of SMEs } & Pearson Correlation & $0.968^{* *}$ & $0.969^{* *}$ & $0.934^{* *}$ & $0.868^{*}$ & 0.013 & $0.981^{* *}$ & 1 & $0.988^{* *}$ \\
\hline & Significant (2-tailed) & 0.000 & 0.000 & 0.002 & 0.011 & 0.978 & 0.000 & - & 0.000 \\
\hline \multirow{2}{*}{ Patents } & Pearson Correlation & $0.940^{* *}$ & $0.964^{* *}$ & $0.930^{* *}$ & $0.833^{*}$ & -0.071 & $0.965^{* *}$ & $0.988^{* *}$ & 1 \\
\hline & Significant (2-tailed) & 0.002 & 0.000 & 0.002 & 0.020 & 0.879 & 0.000 & 0.000 & - \\
\hline
\end{tabular}

Note: ${ }^{*}$ - correlation is significant at the 0.05 level (2-tailed); ${ }^{* *}$ - correlation is significant at the 0.01 level ( 2 -tailed) 
The correlation coefficients of Tau Kendall and Spearman using the SPSS program (Statistical Package for the Social Sciences)

\begin{tabular}{|c|c|c|c|c|c|c|c|c|c|c|}
\hline \multicolumn{3}{|c|}{ Indicators } & $\begin{array}{c}\text { R\&D } \\
\% \text { GDP }\end{array}$ & $\begin{array}{l}\text { Number of } \\
\text { Research }\end{array}$ & $\begin{array}{l}\text { Papers } \\
\text { of 5CI }\end{array}$ & $\begin{array}{c}\text { Papers } \\
\text { of EI }\end{array}$ & $\begin{array}{l}\text { Number } \\
\text { of Students }\end{array}$ & $\begin{array}{l}\text { Number } \\
\text { of 5MEs }\end{array}$ & $\begin{array}{c}\text { Sales } \\
\text { of SMEs }\end{array}$ & $\begin{array}{c}\text { Employed } \\
\text { of 5MEs }\end{array}$ \\
\hline \multirow{9}{*}{ Kendall'stau_b } & R\&D \% GDP & Correlation Coefficient & 1.000 & $0.905^{* *}$ & $0.714^{*}$ & 0.619 & 0.429 & $0.810^{*}$ & $0.905^{* *}$ & $0.905^{* *}$ \\
\hline & Number of Research & Correlation Coefficient & $0.905^{* *}$ & 1.00 & $0.810^{*}$ & $0.714^{*}$ & 0.333 & $0.905^{* *}$ & $1.000^{* *}$ & $1.000^{* *}$ \\
\hline & Papers of 5CI & Correlation Coefficient & $0.714^{*}$ & $0.810^{*}$ & 1.000 & $0.714^{*}$ & 0.524 & $0.714^{*}$ & $0.810^{*}$ & $0.810^{*}$ \\
\hline & Papers of EI & Correlation Coefficient & 0.619 & $0.714^{*}$ & $0.714^{*}$ & 1.000 & 0.619 & 0.619 & $0.714^{*}$ & $0.714^{*}$ \\
\hline & Number of Students & Correlation Coefficient & 0.429 & 0.333 & 0.524 & 0.619 & 1.000 & 0.238 & 0.333 & 0.333 \\
\hline & Number of 5ME & Correlation Coefficient & $0.810^{*}$ & $0.905^{* *}$ & $0.714^{*}$ & 0.619 & 0.238 & 1.000 & $0.905^{* *}$ & $0.905^{* *}$ \\
\hline & Sales of SME & Correlation Coefficient & 0.143 & 0.238 & 0.048 & 0.143 & -0.048 & 0.333 & 0.238 & 0.238 \\
\hline & Employed of SMEs & Correlation Coefficient & $0.905^{* *}$ & $1.000^{* *}$ & $0.810^{*}$ & $0.714^{*}$ & 0.333 & $0.905^{* *}$ & $1.000^{* *}$ & 1.000 \\
\hline & Patents & Correlation Coefficient & $0.905^{* *}$ & $1.000^{* *}$ & $0.810^{*}$ & $0.714^{*}$ & 0.333 & $0.905^{* *}$ & 1.000 & $1.000^{* *}$ \\
\hline \multirow{9}{*}{ Spearman's rho } & R\&D \% GDP & Correlation Coefficient & 1.000 & $0.964^{* *}$ & $0.857^{*}$ & $0.786^{*}$ & 0.536 & $0.893^{* *}$ & $0.964^{* *}$ & $0.964^{* *}$ \\
\hline & Number of Research & Correlation Coefficient & $0.964^{* *}$ & 1.000 & $0.893^{* *}$ & $0.821^{*}$ & 0.429 & $0.964^{* *}$ & $1.000^{* *}$ & $1.000^{* *}$ \\
\hline & Papers of SCI & Correlation Coefficient & $0.857^{*}$ & $0.893^{* *}$ & 1.000 & $0.857^{*}$ & 0.607 & $0.857^{*}$ & $0.893^{* *}$ & $0.893^{* *}$ \\
\hline & Papers of EI & Correlation Coefficient & $0.786^{*}$ & $0.821^{*}$ & $0.857^{*}$ & 1.000 & 0.750 & $0.786^{*}$ & $0.821^{*}$ & $0.821^{*}$ \\
\hline & Number of Students & Correlation Coefficient & 0.536 & 0.429 & 0.607 & 0.750 & 1.000 & 0.286 & 0.429 & 0.429 \\
\hline & Number of SMEs & Correlation Coefficient & $0.893^{* *}$ & $0.964^{* *}$ & $0.857^{*}$ & $0.786^{*}$ & 0.286 & 1.000 & $0.964^{* *}$ & $0.964^{* *}$ \\
\hline & Sales of SMEs & Correlation Coefficient & 0.321 & 0.393 & 0.143 & 0.214 & -0.143 & 0.429 & 0.393 & 0.393 \\
\hline & Employed of SMEs & Correlation Coefficient & $0.964^{* *}$ & $1.000^{* *}$ & $0.893^{* *}$ & $0.821^{*}$ & 0.429 & $0.964^{* *}$ & $1.000^{* *}$ & 1.000 \\
\hline & Patents & Correlation Coefficient & $0.964^{* *}$ & $1.000^{* *}$ & $0.893^{* *}$ & $0.821^{*}$ & 0.429 & $0.964^{* *}$ & 1.000 & $1.000^{* *}$ \\
\hline
\end{tabular}

Note: ${ }^{*}$ - correlation is significant at the 0.05 level (2-tailed); ${ }^{* *}$ - correlation is significant at the 0.01 level (2-tailed)

Table 8 tion. Further, let's calculate the correlation coefficients

The possible value of correlation coefficient

\begin{tabular}{|c|c|}
\hline Values of correlation coefficient & Linear dependence \\
\hline-1 & Functional and negative \\
\hline 0 & Does not exist \\
\hline 1 & Functional and positive \\
\hline$|r|<0.5$ & Weak \\
\hline $0.5 \leq|r| \leq 0.8$ & Average \\
\hline$|r| \geq 0.8$ & Strong \\
\hline
\end{tabular}

Note: ${ }^{*}$ - developed by the author on the basis of [16]

Between the number of registered patents and the number of registered enterprises also showed a high level of correlation: 0.953389(!). This means that innovations have a direct influence on the level of such important economic indicators as - GDP per capita (Between the number of registered patents and GDP per capita the correlation is 0.956656) and employment of the popula- of Pearson, Spearman and Tau Kendall, using the SPSS program (Statistical Package for the Social Sciences) for the rest of the coefficients chosen (Tables 6,7). The obtained data will be formed in the form of Table 10 .

Thus, made economic calculations, using SPSS program showed that the number of students, studying at universities of Taiwan doesn't influence on the indicators related to the number of SMEs and doesn't influence on the number of employed in the field of SMEs. The level of sales of SMEs also has a negative correlation for all the indicators mentioned! Obviously, on these parameters should look for other dependencies.

Let's make the table with indicators which, according to the results of the carried out correlation analysis have showed a high level of the Pearson correlation coefficient (Table 11). However, the other indicators chosen, such as the level of costs for R\&D showed a high impact on the number of SMEs and the level of employed in SMEs of Taiwan that is confirmed by the indicators of correlation $-0.971,0.968$, respectively!

Calculation of the Pearson correlation between GDP per capita, Patents Granted in USA and Number of SMEs in Taiwan, 2008-2014

\begin{tabular}{|l|c|c|c|c|c|c|c|c|}
\hline Indicators & 2008 & 2009 & 2010 & 2011 & 2012 & 2013 & 2014 & 2015 \\
\hline GDP per capita & 18,131 & 16,988 & 19,278 & 20,939 & 21,308 & 21,916 & 22,648 & 22,294 \\
\hline Patents Granted in USA & 6,339 & 6,642 & 8,238 & 8,781 & 10,646 & 11,071 & 11,332 & 11,690 \\
\hline Number of SMEs & $1,234,749$ & $1,232,025$ & $1,247,998$ & $1,279,784$ & $1,306,729$ & $1,331,182$ & $1,353,049$ & $1,383,981$ \\
\hline \multicolumn{7}{|c|}{ Correl: 0.956656 } \\
\hline
\end{tabular}


Calculation of Pearson's correlation coefficients

\begin{tabular}{|c|c|c|c|c|c|c|c|c|c|}
\hline \multicolumn{10}{|c|}{ Pearson Correlation } \\
\hline Pearson Correlation & R\&D \% GDP & $\begin{array}{l}\text { Number of } \\
\text { Reserch }\end{array}$ & $\begin{array}{c}\text { Papers of } \\
\text { 5CI }\end{array}$ & $\begin{array}{c}\text { Papers of } \\
\text { EI }\end{array}$ & $\begin{array}{l}\text { Number of } \\
\text { Students }\end{array}$ & $\begin{array}{l}\text { Number of } \\
\text { SMEs }\end{array}$ & $\begin{array}{l}\text { Sales of } \\
\text { SMEs }\end{array}$ & $\begin{array}{l}\text { Employed of } \\
\text { SMEs }\end{array}$ & Patents \\
\hline R\&D \% GDP & 1 & $0.906^{* *}$ & $0.891^{* *}$ & $0.836^{*}$ & 0.145 & $0.971^{* *}$ & -0.076 & $0.968 * *$ & 0.940 \\
\hline Number of Reserch & $0.906^{* *}$ & 1 & $0.972^{* *}$ & $0.880^{* *}$ & 0.056 & $0.906 * *$ & -0.230 & $0.969^{* *}$ & $0.964^{* *}$ \\
\hline Papers of 5CI & $0.891^{* *}$ & $0.972^{* *}$ & 1 & $0.895^{* *}$ & 0.154 & $0.874^{*}$ & -0.388 & $0.934^{* *}$ & $0.930^{* *}$ \\
\hline Рарегs of EI & $0.836^{*}$ & $0.880^{* *}$ & $0.895^{* *}$ & 1 & 0.390 & $0.818^{*}$ & -0.076 & $0.868 *$ & 0.833 \\
\hline Number of Students & 0.145 & 0.056 & 0.154 & 0.390 & 1 & -0.044 & -0.114 & 0.013 & -0.071 \\
\hline Number of SMEs & $0.971^{* *}$ & $0.906^{* *}$ & $0.874^{*}$ & $0.818^{*}$ & -0.044 & 1 & 0.000 & $0.981^{* *}$ & $0.965 * *$ \\
\hline Sales of SMEs & -0.076 & -0.230 & -0.388 & -0.076 & -0.114 & 0.000 & 1 & -0.082 & -0.110 \\
\hline Employed of SMEs & $0.968 * *$ & $0.969 * *$ & $0.934^{* *}$ & $0.868^{*}$ & 0.013 & $0.981^{* *}$ & -0.082 & 1 & $0.988^{* *}$ \\
\hline
\end{tabular}

Note: ${ }^{*}$ - correlation is significant at the 0.05 level (2-tailed); ${ }^{* *}$ - correlation is significant at the 0.01 level (2-tailed)

Table 11

Calculation of Pearson correlation - influence on the number of small and medium-sized enterprises (5MEs) and employed in 5MEs in Taiwan

\begin{tabular}{|c|c|c|c|c|c|c|c|}
\hline Pearson Correlation & R\&D \% GDP & Number of Reserch & Papers of 5CI & Papers of EI & Number of SMEs & Employed of 5MEs & Patents \\
\hline R\&D \% GDP & 1 & $0.906^{* *}$ & $0.891^{* *}$ & $0.836^{*}$ & $0.971^{* *}$ & 0.940 & 0.940 \\
\hline Number of Reserch & $0.906 * *$ & 1 & $0.972^{* *}$ & $0.880^{* *}$ & $0.906 * *$ & $0.964^{* *}$ & $0.964^{* *}$ \\
\hline Papers of 5CI & $0.891^{* *}$ & $0.972^{* *}$ & 1 & $0.895^{* *}$ & $0.874 *$ & $0.930^{* *}$ & $0.930^{* *}$ \\
\hline Рapers of EI & $0.836^{*}$ & $0.880^{* *}$ & $0.895^{* *}$ & 1 & $0.818^{*}$ & 0.833 & 0.833 \\
\hline Number of 5MEs & $0.971^{* *}$ & $0.906^{* *}$ & $0.874^{*}$ & $0.818^{*}$ & 1 & $0.981^{* *}$ & $0.965^{* *}$ \\
\hline Employed of SMEs & $0.968^{* *}$ & $0.969^{* *}$ & $0.934^{* *}$ & $0.868^{*}$ & $0.981^{* *}$ & 1 & $0.988^{* *}$ \\
\hline Patents & $0.940^{* *}$ & $0.964^{* *}$ & $0.930^{* *}$ & $0.833^{*}$ & $0.965 * *$ & $0.988^{* *}$ & 1 \\
\hline
\end{tabular}

Note: ${ }^{*}$ - correlation is significant at the 0.05 level (2-tailed); ${ }^{* *}$ - correlation is significant at the 0.01 level (2-tailed)

The number of researchers and their publications also has a high impact on the number of enterprises in SMEs and employed employees in it and this is confirmed by the Pearson correlation coefficients which make up more than 0.9 in all mentioned indicators. It should be noted that the calculated correlation coefficients of Spearman and Tau Kendall confirm the calculations obtained by the author. In calculating the correlation of Tau Kendall is shown not high -0.619 , but the dependence of the influence of number of students on the level of publications. Perhaps, this reflects the participation of students in scientific work in the form of provision of publications. Other calculations obtained by the author on the correlation coefficients by the methods of Spearman and Tau Kendall haven't revealed significant deviations in the presented calculations of the Pearson correlation.

\section{SWOT analysis of research results}

Strengths. The research was based on the econometrics methods - correlation and regression analysis. To assess the factors affecting on the creation of SMEs and innovation activities in Taiwan, were author used only those correlation and determination coefficients that had high values: $0.8-0.9$. It is confirms the correctness of the recommendations.

Weaknesses. There is no access to the statistical database of publications of researchers and patents by industry in Taiwan, do not allow the formulation of recommendations for a specific industry in the country.
Opportunities. The research has shown that problems of implementation of the innovation in Taiwan related to the number of researchers in the country, their publications and as a result of a number of patents. Also should be considered to the impact of expenditures on $R \& D$ as a percentage of GDP. It can be recommended for the formation of the countrys economics policy.

Threats. For the implementation of the results should be to test this method, based on the example of other states. Analysis by the industry will show different results.

\section{Conclusions}

1. The research showed that SMEs be included in the innovation process. There are several reasons why small firms concentrate on the innovation efforts. First, these breakthroughs where small firms may be particularly common for the types of processes in which firm specialize. Second, they may occur because the comparative advantage of large firms lies in the production of the type of knowledge that originates in $R \& D$ facilities. Since the costs of conducting R\&D for large firms are lower because specialization of function means that large firms will enjoy cost advantages in the pure R\&D function. A small firm may be just an innovative, but the may innovate in unique ways. Most previous studies have focused on the whether R\&D expenditures increase more scale in the $R \& D$ function or whether R\&D expenditures increase more than proportionally with firm size. 
2. The establishment of a linear relationship and the use of the correlation analysis of Pearson, Spearman and Tau Kendall, using SPSS program allowed the author to find the relationship between the indicators. Thus, between GDP per capita and the number of registered patents in Taiwan there is a high interrelation - the level of correlation made up 0.9533 , but the level of correlation between the number of registered patents of SMEs also showed a high level $-0.9566(!)$. This means that innovations have direct influence on the level of such important economic indicators as GDP per capita and employment of the population.

3. The number of researchers of Taiwan and the number of their publications also have a direct impact on the number of SMEs and employed employees in it and this is confirmed by the coefficients of Pearson correlation, which make up more than 0.9 of all mentioned indicators. However, made econometric calculations, using the SPSS program showed that the number of students, studying at the universities of Taiwan doesn't influence on the indicators related to the number of firms of SMEs and doesn't influence on the number of employed in the field of SMEs. The level of sales of SMEs also has a negative correlation for all of the indicators provided. Obviously, on these parameters should look for other dependencies.

Thus, for the successful involvement of SMEs in the innovative activities of the country, it is necessary to support funding for research and development, to motivate scientists to engage in scientific activities (publications ect).

\section{Acknowledgements}

The research support by the Ministry of Foreign Affairs in Taiwan in 2018.

\section{References}

1. Baldwin J. R., Hanel P. The Economics of Knowledge Creation // Innovation and Knowledge Creation in an Open Economy. Cambridge University Press, 2003. P. 1-28. doi: http://doi.org/ $10.1017 /$ cbo9780511510847.001

2. European Private Equity and Venture Capital Association (EVCA) // International Year Book and Statesmen's Who's Who. Brill. doi: http://doi.org/10.1163/1570-6664_iyb_sim_org_39248
3. The Global Competitiveness Report 2017-2018 // World Economic Forum. URL: https://www.weforum.org/reports/the-globalcompetitiveness-report-2017-2018

4. Hollanders H., Es-Sadki N., Kanerva M. European Innovation Scoreboard 2016. European Union, 2016. URL: https://www. knowledgetransferireland.com/Reports-Publications/EuropeanInnovation-Scoreboard-2016.pdf

5. Chen S.-J. The Effects of Social Networks and a Global Mindset on Taiwanese Manufacturing SMES' Ability to Form Alliances to Increase International and Financial Performance. San Diego: Alliant International University, Alliant School of Management, 2013. 760 p.

6. Gross domestic expenditure on R\&D (GERD) of GDP Eurostat. URL: http://ec.europa.eu/eurostat/tgm/table.do?t $\mathrm{ab}=$ table \&init $=1 \&$ language $=$ en $\&$ pcode $=\mathrm{t} 2020 \_20 \&$ plugin $=1$

7. Taiwan Statistical Data Book 2018 // National Development Council. URL: https://www.ndc.gov.tw/en/News_Content.asp $\mathrm{x} ? \mathrm{n}=607 \mathrm{ED} 34345641980 \& \mathrm{sms}=\mathrm{B} 8 \mathrm{~A} 915763 \mathrm{E} 368 \overline{4} \mathrm{AC} \& \mathrm{~s}=\mathrm{B} 3 \mathrm{~B}$ 7911F9063C $75 \mathrm{~F}$

8. Bieńkowska E., Moedas C. European Innovation Scoreboard 2017. URL: https://www.rvo.nl/sites/default/files/2017/06/ European_Innovation_Scoreboard_2017.pdf

9. Central Statistical Bureau of Latvia. URL: https://www.csb. gov.lv/en/

10. Baldwin J. R., Hanel P. Research and Development and Innovation // Innovation and Knowledge Creation in an Open Economy. Cambridge University Press, 2003. P. 96-129. doi: http:// doi.org/10.1017/cbo9780511510847.005

11. Hoyos López M. Trade liberalization and premature deindustrialization in Colombia // Journal of Economic Structures. 2017. Vol. 6, Issue 1. doi: http://doi.org/10.1186/s40008-017-0095-6

12. European Commission. 1997. URL: http://europa.eu/rapid/ press-release IP-96-1133_en.htm

13. Baldwin J. R., Hanel P. Innovation and Research and Development in Small and Large Firms // Innovation and Knowledge Creation in an Open Economy. Cambridge University Press, 2003. P. 156-184. doi: http://doi.org/10.1017/ cbo9780511510847.007

14. Soete L. L. G. Firm size and inventive activity // European Economic Review. 1979. Vol. 12, Issue 4. P. 319-340. doi: http:// doi.org/10.1016/0014-2921(79)90024-2

15. White Paper on Small and Medium Enterprises in Taiwan, 2009-2017 // Small and Medium Enterprise Administration, Ministry of Economic Affairs. URL: https://www.moeasmea. gov.tw $/$ p.asp? ctNode $=307 \&$ CtUnit $=36 \&$ BaseDSD $=7 \& \mathrm{mp}=2$

16. Orekhov A. M. Metody ekonomicheskikh issledovaniy. Moscow: INFRA-M, 2009.392 p.

Stecenko Inna, Doctor of Economic Sciences, Professor, Baltic Inter national Academy, Riga, Latvia, e-mail: stecenkoinna15@gmail.com, ORCID: http://orcid.org/0000-0002-0277-286X 